Loyalitas Kreativitas
Aldi Masyarakat Kreatif

P-ISSN 2722-2101, E-ISSN 2722-4201

Program Studi Ekonomi Manajemen Universitas Pamulang

Jurnal LOKABMAS Kreatif Vol.01,No.02 Juli 2020, Hal. 88-95

Email:jurnalkreatif.manajemen@gmail.com

\title{
PROGRAM PEMBANGUNAN, PENGEMBANGAN SERTA PENIGKATAN KUALITAS KOMPETENSI SDM PADA GENERASI MUDA YANG UNGGUL DAN SIAP BERSAING DI ERA INDUSTRI 4.0
}

\author{
Hendri Gunawan, Muhamad Guruh, Henni Marlinah, \\ Nurdinni Tilova, Devi Putri Isnaeni \\ Dosen Ekonomi Fakultas Ekonomi Universitas \\ Pamulang \\ Email : dosen02218@unpam.ac.id, \\ dosen01675@unpam.ac.id,
}

\begin{abstract}
ABSTRAK
Pengabdian Kepada Masyarakat ini berjudul Program Pembangunan, Pengembangan Serta Peningkatan Kualitas Kompetensi SDM Pada Generasi Muda Yang Unggul Dan Siap Bersaing Di Era Industri 4.0.

Tujuan dilaksanakannya kegiatan pengabdian masyarakat adalah untuk memberikan penyuluhan serta tanya jawab akan arti pentingnya meningkatkan kualitas kompetensi diri agar dapat meningkatkan daya saing tenaga kerja di Indonesia. Pemuda sangat dituntut beradaptasi dengan cepat dalam mengahapi perubahan yang terjadi dalam era Revolusi Industri 4.0 ini, maka penting untuk menguasai serta meningkatkan keahlian (skill).

Metode kegiatan pengabdian kepada masyarakat ini berlangsung dari bulan Mei sampai dengan Juni 2020 dan terdiri dari tiga tahapan kegiatan. Tahapan pertama yaitu tahap persiapan dalam melakukan survey lokasi mitra, peserta kegiatan dan penyusunan materi. Tahap ke dua yaitu pelaksanaan yang meliputi pemberian ceramah materi pembangunan, pengembangan serta peningkatan kualitas kompetensi SDM pada generasi muda yang unggul dan siap bersaing di era industri 4.0. Tahap ketiga yaitu evaluasi antara lain untuk mengetahui seberapa dalam pemahaman peserta pelatihan terhadap materi yang diberikan.

Kesimpulan dari kegiatan pengabdian masyarakat ini adalah para siswa dan guru SMK Muhammadiyah Parakan antusias dalam menerima ilmu baru dan aktif melakukan tanya jawab mengenai bagaimana cara membangun, mengembangkan dan meningkatkan kualitas kompetensi SDM, serta strategi apa yang perlu dilakukan agar mudah bersaing di era industry 4.0.
\end{abstract}

Kata Kunci : Kompetensi SDM, Era Industri 4.0

ABSTRAC

This Community Service is titled The Program of Developing and Improving the Quality of Human Resources Competence in the Young Generation that is Excellent and Ready to Compete in the Industrial4.0 Era.

The purpose of carrying out community service activities is to provide counseling and question and answer on the importance of improving the quality of self-competence in order to improve the competitiveness of the workforce in Indonesia. Youth are very demanded to adapt quickly in responding to changes that occur in the era of the Industrial Revolution 4.0, it is important to master and improve skills.

The method of community service activities takes place from May to June 2020 and consists of three stages of activity. The first stage is the stage of preparation in conducting survey of partner locations, participant activities and preparation of material. The second stage is the implementation of lectures on development, development and improvement of the quality of human resources competencies for young people who are superior and ready to compete in the industrial 4.0 era. The third stage is the evaluation, among others, to find out how deep the participants' understanding of the material provided.

The conclusion of this community service activity are students and teachers of SMK Muhammadiyah Parakan are enthusiastic in accepting new knowledge and actively asking questions about how to build, develop and improve the quality of HR competencies, as well as what strategies need to be done so that they can easily 


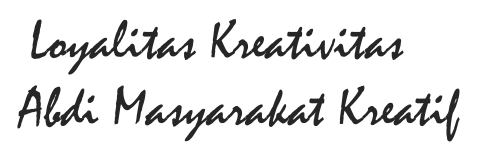

P-ISSN 2722-2101, E-ISSN 2722-4201

Program Studi Ekonomi Manajemen Universitas Pamulang

Jurnal LOKABMAS Kreatif Vol.01,No.02 Juli 2020, Hal. 88-95

Email:jurnalkreatif.manajemen@gmail.com

compete in the industrial era 4.0.

Keywords: HR Competency, Industrial 4.0 Era

\section{PENDAHULUAN}

Pembangunan Sumber Daya Manusia (SDM) menjadi pengaruh utama strategi pembangunan bangsa Indonesia ke depan, piliha strategi tersebut diupayakan untuk mengakselerasi pertumbuhan ekonomi yang dibutuhkan dalam meningkatkan kesejahteraan rakyat.

Urgensi pembangunan sumber daya manusia menjadi faktor kunci dalam memenangkan persaingan global, yang membawa konsekuensi semakin ketatnya persaingan di tengah ketidakpastian, langkah strategis ini sudah selayaknya mendapatkan dukung penuh dari seluruh pemangku kepentingan.

Penguatan sumber daya manusia menuju manusia unggul memiliki korelasi yang erat dengan peningkatan produktivitas kerja, dalam memenangkan persaingan di tengah perubahanperubahan yang berlangsung cepat dalam dunia bisnis, ekonomi politik dan budaya.

Apalagi dengan adanya era industry 4.0, tentunya kita harus bisa bersaing dan memiliki nilai jual lebih. Apa sebenarnya industry 4.0 itu? Menurut sumber Wikipedia, Industri 4.0 adalah nama tren otomasi dan pertukaran data terkini dalam teknologi pabrik. Istilah ini mencakup sistem siber-fisik, internet untuk segala, komputasi awan, dan komputasi kognitif.

Industri 4.0 menghasilkan "pabrik cerdas". Di dalam pabrik cerdas berstruktur moduler, sistem siber-fisik mengawasi proses fisik, menciptakan salinan dunia fisik secara virtual, dan membuat keputusan yang tidak terpusat. Lewat Internet untuk segala (IoT), sistem siber-fisik berkomunikasi dan bekerja sama dengan satu sama lain dan manusia secara bersamaan. Lewat komputasi awan, layanan internal dan lintas organisasi disediakan dan dimanfaatkan oleh berbagai pihak di dalam rantai nilai.

Seiring dengan semakin sedikitnya lapangan kerja, berwirausaha bisa menjadikan alternatif pilihan bagi beberapa orang yang memiliki jiwa usaha, baik untuk kalangan kecil, menengahn sampai besar. Berwirausaha merupakan salah satu peluang yang sangat menjanjikan untuk ditekuni dalam menghasilkan pundi-pundi rupiah.

Menurut

Suryana (2003:1), kewirausahaan adalah kemampuan kreatif dan inovatif yang dijadikan dasar, kiat, dan sumber daya untuk mencari peluang menuju sukses. Inti dari kewirausahaan adalah kemampuan untuk menciptakan sesuatu yang baru dan berbeda (create new and different) melalui berfikir kreatif dan bertindak inovatif untuk menciptakan peluang.

Dalam memulai, menjalankan dan mengembangkan kegiatan usaha sangatlah tidak mudah. Dalam hal ini sangat memerlukan perhitungan yang matang dalam setiap pengambilan keputusan untuk mengelola semua modal usaha yang dimiliki. Salah perhitungan saja, bisa jadi usaha akan mengalami kebangkrutan.

Di sisi lain, terdapat permasalahan yang cukup serius di dunia kerja kita. SMK yang diharapkan dapat menangani masalah pengangguran di Indonesia belum berfungsi dengan sebagaimana mestinya. Data menunjukan bahwa pengangguran tertinggi di Indonesia adalah lulusan SMK yaitu sebesar 11,24\% (BPS, 2018). Dibandingkan dengan pengangguran lulusan SD yang hanya 2,43 persen dan pengangguran lulusan SMP sebesar 4,8 persen, angka yang ditunjukkan oleh pengangguran lulusan SMK adalah hal yang ironis. Hal ini tentu harus menjadi perhatian para pemangku kebijakan sebab, menurut Peraturan Presiden Nomor 41 Tahun 2015 tentang 2 Grand Design Pengembangan Teaching Factory, pendidikan SMK belum mampu merealisasikan tujuan awalnya yaitu membantu menjembatani celah yang ada antara industri dan dunia pendidikan.

Siswa siswi SMK Muhammadiyah Parakan ini masih belum menentukan pilihan setelah lulus sekolah, diharapkan generasi muda saat ini untuk memiliki kesadaran akan pentingnya keahlian (skill/), karena dengan adanya industry 4.0 maka akan semakin sedikitnya lapangan kerja dikarenakan banyaknya tenaga kerja manusia yang digantikan oleh tenaga mesin serta semakin tingginya persaingan.

Dengan diberlakunya MEA (Masyarakat Ekonomi ASEAN), maka masyarakat khususnya para pemuda generasi bangsa perlu meningkatkan kualitas kompetensinya agar dapat bersaing dengan masyarakat dari negara ASEAN lainnya.

Ada beberapa alternatif yang bisa dilakukan dalam hal ini salah satunya, yaitu dengan memanfaatkan peluang usaha online. Bisnis online juga 


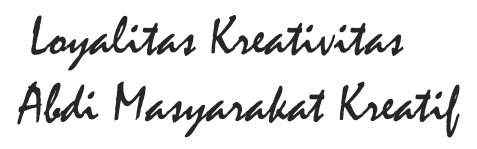

P-ISSN 2722-2101, E-ISSN 2722-4201

Program Studi Ekonomi Manajemen Universitas Pamulang

Jurnal LOKABMAS Kreatif Vol.01,No.02 Juli 2020, Hal. 88-95

Email:jurnalkreatif.manajemen@gmail.com bisa di katakan sebagai kerja online, dimana kita bekerja secara online di internet dan mendapatkan penghasilan di internet. Kerja online sendiri bersifat bebas waktu kerjanya sehingga sangat cocok di jadikan sebagai usaha sampingan, dan juga dapat diakses diberbagai Negara.

Untuk membantu dalam masalah ini maka kami akan mensosialisasikan dan memberikan penyuluhan kepada siswa SMK Muhamadiyah Parakan, dengan tema "Program Pembangunan, Pengembangan Serta Peningkatan Kualitas Kompetensi SDM Pada Generasi Muda Yang Unggul Dan Siap Bersaing Di Era Industri 4.0”.

\section{RUMUSAN MASALAH}

Dalam program yang akan kami ajukan terdapat beberapa masalah yang perlu dirumuskan, antara lain sebagai berikut :

1. Bagaimana membangun kualitas kompetensi SDM di era industri 4.0?

2. Bagaimana mengembangkan kualitas kompetensi SDM di era industri 4.0?

3. Bagaimana meningkatkan kualitas kompetensi SDM di era industri 4.0?

4. Kompetensi apa yang diperlukan di era industri 4.0?

5. Bagaimana memenangkan persaingan di era industri 4.0?

6. Apa saja peluang besar di era industri 4.0?

\section{TUJUAN PELAKSANAAN}

Adapun tujuan dan manfaat dari dilakukannya kegiatan pengabdian kepada masyarakat (PKM) sebagai berikut:

1. Mengetahui cara membangun kualitas kompetensi SDM di era industri 4.0.

2. Mengetahui cara mengembangkan kualitas kompetensi SDM di era industri 4.0.

3. Mengetahui cara meningkatkan kualitas kompetensi SDM di era industri 4.0.

Mengetahui kompetensi yang diperlukan di era industri 4.0.

4. Mengetahui cara memenangkan persaingan di era industri 4.0.

5. Mengetahui berbagai peluang besar di era industri 4.0.

\section{TINJAUAN PUSTAKA \\ Kompetensi SDM}

Pengertian Kompetensi SDM Menurut Wibowo (2013:324), kompetensi adalah suatu kemampuan untuk melaksanakan atau melakukan suatu pekerjaan atau tugas yang dilandasi atas keterampilan dan pengetahuan serta didukung oleh sikap kerja yang dituntut oleh pekerjaan tersebut. Dengan demikian, kompetensi menunjukan keterampilan atau pengetahuan yang dicirikan oleh profesionalisme dalam suatu bidang tertentu sebagai sesuatu yang terpenting, sebagai unggulan bidang tersebut.

Mangkunegara

(2005:113)

mengemukakan, bahwa kompetensi merupakan faktor mendasar yang dimiliki seseorang yang mempunyai kemampuan lebih, yang membuatnya berbeda dengan seseorang yang mempunyai kemampuan rata-rata atau biasa saja.

Menurut Mangkunegara (2012:40), kompetensi sumber daya manusia adalah kompetensi yang berhubungan dengan pengetahuan, keterampilan, kemampuan dan karakteristik kepribadian yang mempengaruhi secara langsung terhadap kinerjanya.

Kompetensi sumber daya manusia menurut hasil kajian Perrin yaitu :

1. Memiliki kemampuan komputer (Eksekutif Lini)

2. Memiliki pengetahuan yang luas tentang visi

3. Memiliki kemampuan mengantisipasi pengaruh perubahan

4. Memiliki kemampuan memberikan pendidikan tentang sumber daya manusia.

Sehingga dapat disimpulkan bahwa kompetensi sumber daya manusia adalah kemampuan yang dimiliki seseorang yang berhubungan dengan pengetahuan, keterampilan dan karakteristik seseorang yang mempengaruhi kinerjanya untuk mencapai tujuan yang diinginkan.

- Jenis Kompetensi

Jenis kompetensi terbagi menjadi dua, yaitu:

- Soft Kompetensi

Soft kompetensi adalah kompetensi yang berhubungan dengan kemampuan mengelola pegawai, serta membangun hubungan dengan orang lain.

Seperti pemecahan masalah yang kompleks, pikiran yang kritis, kreativitas, manajemen manusia, berkoordinasi dengan orang lain,

kecerdasan emosional, penilaian dan pengambilan keputusan, berorientasi servis, negosiasi, dan fleksibilitas kognitif.

- Hard Kompetensi

Hard kompetensi adalah kompetensi yang berhubungan dengan kapasitas fungsional sebuah pekerjaan dan berkaitan dengan keteknisan yang berhubugan dengan pekerjaan yang dijalankan.

Seperti kemampuan pemasaran/marketing, 


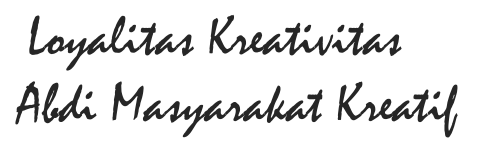

P-ISSN 2722-2101, E-ISSN 2722-4201

Program Studi Ekonomi Manajemen Universitas Pamulang

Jurnal LOKABMAS Kreatif Vol.01,No.02 Juli 2020, Hal. 88-95

Email:jurnalkreatif.manajemen@gmail.com akuntansi, produksi, keuangan, dan lain-lain.

\section{Era Industri 4.0}

Revolusi industry yaitu perubahan yang cepat di bidang ekonomi dari kegiatan ekonomi agraris ke ekonomi industri yang menggunakan mesin dalam mengolah bahan mentah menjadi bahan siap pakai.

Ada beberapa revolusi industri sampai saat ini, yaitu:

- Industri 1.0

Revolusi industri yang pertama terjadi pada abad ke-18 ditandai dengan penemuan mesin uap yang digunakan untuk proses produksi barang. Saat itu, di Inggris, mesin uap digunakan sebagai alat tenun mekanis pertama yang dapat meningkatkan produktivitas industri tekstil. Peralatan kerja yang awalnya bergantung pada tenaga manusia dan hewan akhirnya digantikan dengan mesin tersebut.

\section{- Industri 2.0}

Revolusi industri 2.0 terjadi di awal abad ke-20. Revolusi industri ini ditandai dengan penemuan tenaga listrik. Tenaga otot yang saat itu sudah tergantikan oleh mesin uap, perlahan mulai tergantikan lagi oleh tenaga listrik. Walaupun begitu, masih ada kendala yang menghambat proses produksi di pabrik, yaitu masalah transportasi.

\section{- $\quad$ Industri 3.0}

Jika revolusi pertama dipicu oleh mesin uap, revolusi kedua dipicu oleh ban berjalan dan listrik, revolusi ketiga ini dipicu oleh mesin yang dapat bergerak dan berpikir secara otomatis, yaitu computer dan robot.

- Industri 4.0

Revolusi industri 4.0 merupakan perpaduan system teknologi fisik, digital, dan biologis yang merubah cara hidup manusia, yang menghasilkan kecerdasan buatan, koneksi antara mesin ataupun alat fisik lain dengan system internet, rekayasa genetika, kendaraan otonom, big data, penggunaan internet sebagai pusat penyimpanan dan pengelolaan data, neuroteknologi, dan percetakan 3D.

\section{METODE PELAKSANAAN Kerangka Pemecahan Masalah}

Dari uraian analisis situasi, maka dapat dibuat kerangka pemecahan masalah yang dihadapi, antara lain:

1. Memberikan penjelasan dan pemahaman bagaimana cara membangun kualitas kompetensi SDM di Era Industri 4.0.

2. Memberikan penjelasan dan pemahaman bagaimana cara mengembangkan kualitas kompetensi SDM di era industri 4.0.

3. Memberikan penjelasan dan pemahaman bagaimana cara meningkatkan kualitas kompetensi SDM di era industri 4.0.

4. Memberikan penjelasan dan pemahaman standar kompetensi yang diperlukan di era industri 4.0.

5. Memberikan penjelasan dan pemahaman strategi untuk memenangkan persaingan di era industri 4.0.

6. Memberikan penjelasan dan pemahaman beberapa peluang besar di era industri 4.0.

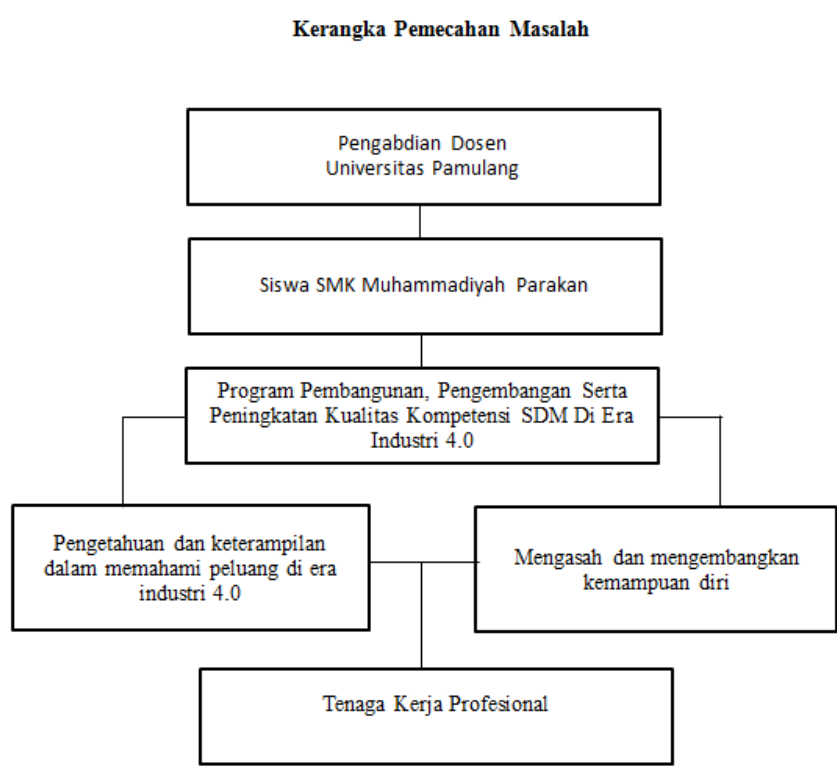

\section{Realisasi Pemecahan Masalah}

Siswa SMK Muhammadiyah Parakan setelah mengikuti penyuluhan ini dapat memahami cara membangun, mengembangkan, serta meningkatkan kualitas kompetensi diri, dan siswa dapat mengetahui apa saja peluang besar di industry 4.0, serta mempunyai strategi untuk memenangkan persaingan di industry 4.0, sehingga mereka akan lebih siap menghadapi era industry 4.0.

\section{- Khalayak Sasaran}

Khalayak sasaran kegiatan pengabdian kepada masyarakat ini adalah siswa SMK Muhammadiyah Parakan, Pamulang, Kota Tangerang Selatan. Dengan jumlah khalayak sasaran kurang lebih 23 orang.

\section{- Tempat dan Waktu Pelaksanaan}

Pelaksanaan kegiatan pengabdian kepada masyarakat yang dilakukan oleh dosen prodi 


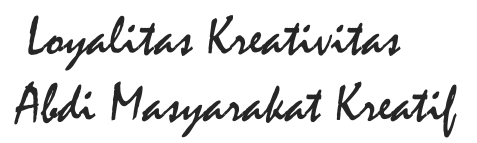

P-ISSN 2722-2101, E-ISSN 2722-4201

Program Studi Ekonomi Manajemen Universitas Pamulang

Jurnal LOKABMAS Kreatif Vol.01,No.02 Juli 2020, Hal. 88-95

Email:jurnalkreatif.manajemen@gmail.com

\author{
Manajemen Universitas Pamulang ini \\ dilaksanakan pada: \\ Tempat: SMK Muhammadiyah Parakan. Jln. \\ Benda Barat 11, Komp. Ritan, RT 03, RW 09, Kp. \\ Parakan, Kel. Pondok Benda, Kec. Pamulang Kota \\ Tangerang Selatan, Banten. \\ Waktu : Sabtu, 13 Juni 2020.

\section{- Metode Kegiatan}

Metode kegiatan yang dilakukan kepada siswa sekolah SMK Muhammadiyah Parakan adalah berupa pelatihan langsung dengan tatap muka di kelas melibatkan siswa kelas 10, kelas 11 dan guru di sekolah tersebut, selanjutnya forum diskusi interaktif dengan siswa di kelas, dengan adanya forum diskusi ini memberikan fasilitas kepada siswa untuk mengajukan pertanyaan-pertanyaan terkait kompetensi SDM di Era Industri 4.0.

Program Pengabdian kepada Masyarakat di sekolah SMK Muhammadiyah Parakan dibagi menjadi 3 tahap yaitu, tahap pertama persiapan, melakukan survei lapangan, tahap kedua pelaksanaan yaitu pemberian materi dan pelatihan, dan tahap ketiga evaluasi. Berikut adalah alur dari setiap rangkaian kegiatan:

\section{-Tahap Persiapan}

Adapun tahap-tahap yang dilakukan dalam Pengabdian kepada Masyarakat meliputi:

Survei awal, pada tahap ini dilakukan ke lokasi sekolah SMK Muhammadiyah Parakan, Pamulang, Kota Tangerang Selatan.

Setelah survei maka ditetapkannya waktu pelaksanaan dan sasaran peserta kegiatan. Penyusunan bahan/materi pelatihan

\section{-Tahap Pelaksanaan}

Permasalahan yang ada bahwa siswa siswi SMK Muhammadiyah Parakan ini masih belum menentukan pilihan setelah lulus sekolah, diharapkan generasi muda saat ini untuk memiliki kesadaran akan pentingnya keahlian (skill/), karena dengan adanya industry 4.0 maka semakin sedikitnya lapangan kerja dan semakin tingginya persaingan.

Waktu pelaksanaan program Pengabdian kepada Masyarakat ini berjalan pada hari Sabtu tanggal 13 Juni 2020. Program PKM ini dilaksanakan di sekolah SMK Muhammadiyah Parakan,

\section{HASIL DAN PEMBAHASAN}

Menurut Undang-Undang Nomor 40 Tahun 2009 tentang Kepemudaan, definisi pemuda adalah mereka yang berusia 18 hingga 35 Tahun. Kami
Pamulang, Kota Tangerang Selatan.

Kegiatan PKM yang dilakukan pada sekolah SMK Muhammadiyah Parakan menggunakan metode berikut ini :

Ceramah materi pelatihan melibatkan anak anak kelas 10, kelas 11 dan guru di sekolah tersebut Dosen Univeristas Pamulang memberikan materi terkait pengetahuan dalam membangun, mengembangkan dan meningkatkan kualitas kompetensi SDM di era industry 4.0, bagaimana cara memenangkan persaingan di era industry 4.0, dan apa saja peluang besar di era industry 4.0.

Forum diskusi interaktif dengan siswa

di kelas Dengan adanya forum diskusi ini kami memberikan fasilitas kepada siswa dan guru untuk mengajukan pertanyaan-pertanyaan terkait kompetensi SDM di era industry 4.0. Melalui kegiatan ini juga para siswa dan guru diberikan kesempatan untuk mengungkapkan pandangannya dalam memecahkan masalah terkait kompetensi SDM di era industry 4.0.

Untuk kegiatan-kegiatan yang dilakukan di dalam ruangan, digunakan alat bantu microphone, sebagai pengeras suara. Selain itu, untuk lebih memberikan gambaran visualisasi yang menarik dan jelas, maka setiap kegiatan yang dilakukan menggunakan proyektor dan laptop. Setiap kegiatan yang dilaksanakan dalam program ini didokumentasikan dalam bentuk foto dan video.

Tahap Evaluasi

Pada tahap evaluasi ini untuk mengetahui seberapa dalam pemahaman peserta pelatihan terhadap materi yang diberikan dilakukan pendampingan, sosialisasi dan pelatihan secara langsung kepada peserta kegiatan secara bersama dengan mendatangi secara langsung sekolah SMK Muhammadiyah Parakan. Proses diskusi saat proses pelatihan ini sangat penting sebagai bahan evaluasi apakah PKM yang telah kita lakukan sudah berhasil atau belum. Tahap evaluasi ini dilaksanakan selama proses pelatihan berlangsung. Dalam tahap ini dilakukan sesi diskusi dan tanya jawab terhadap keaktifan dan kepuasan peserta.

selaku peneliti melakukan penyuluhan kepada Siswa SMK Muhammadiyah Parakan karena ingin memberikan pengetahuan kepada pelajar yang berusia di bawah 18 tahun bahwa di masa yang akan datang mereka dituntut memiliki kompetensi yang beragam menyesuaikan dengan era Industri 4.0. 


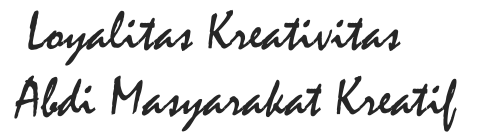

P-ISSN 2722-2101, E-ISSN 2722-4201

Program Studi Ekonomi Manajemen Universitas Pamulang

Jurnal LOKABMAS Kreatif Vol.01,No.02 Juli 2020, Hal. 88-95

Email:jurnalkreatif.manajemen@gmail.com
Saat ini kita sudah memasuki era industri 4.0 yang ditandai dengan pemanfaatan teknologi, dimana teknologi kecerdasan buatan, teknologi robotic, dan internet saling mempengaruhi dalam kehidupan sehari-hari. Teknologi kecerdasan buatan akan menghilangkan beberapa pekerjaan. Agar mampu menghadapi industry 4.0 seseorang perlu memiliki kompetensi yang berkualitas agar dapat bersaing pada kondisi ini.

Untuk mampu menghadapi industry 4.0, Siswa SMK Muhammadiyah Parakan juga perlu membangun kompetensi dalam dirinya dengan cara belajar secara teoritis, yakni menggali pengetahuan di sekolah, serta mempraktekkan dan mengaplikasikan ilmu yang di dapat.

Upaya yang dapat dilakukan untuk mengembangkan kompetensi, yakni dengan cara mengikuti beberapa program pelatihan, perbanyak studi banding, mengikuti pendidikan formal/non formal, tantang diri dengan hal-hal baru yang bermanfaat dan perbanyak kesempatan magang kerja.

Adanya revolusi industri 4.0 maka semakin sedikitnya lapangan kerja dan semakin tingginya persaingan. Agar siswa SMK Muhammadiyah Parakan dapat memenangkan persaingan di era idustri 4.0 perlu adanya strategi yang menyembataninya, yaitu dengan cara terus belajar meningkatkan kompetensi, pahami kekurangan dan kelebihan pribadi, pelajari kekuatan dan kelemahan lawan, memaksimalkan setiap kesempatan yang ada, tidak menyerah dan terus mencoba.

Beberapa kompetensi yang diperlukan industri 4.0, yaitu:

- Kemampuan berbahasa asing. Kemampuan ini penting dikuasai agar dapat berkomunikasi pada tingkat global.

- Kemampuan berpikir kritis. Kemampuan ini dapat ditingkatkan melalui kebiasaa membaca dan berdiskusi secara intensif.

- Kreativitas. Kemampuan untuk menemukan sesuatu yang unik. Menciptakan inovasi-inovasi baru atau mengembangkan yang sudah ada.

- $\quad$ Leadership. Kemampuan untuk mengatur. Bagi mahasiswa ataupun siswa, hal ini dapat dikembangkan saat mereka mengikuti organisasi ataupun ekstrakulikuler.

- Kecerdasan emosional. Dalam hal ini, termasuk pula kemampuan untuk mengelola, dan memanfaatkan emosi.

Peluang industri 4.0

Dengan adanya industri 4.0 maka banyak peluang bisnis yang bisa dilakukan, salah satunya bisnis jual beli online. Bisnis jual beli online semakin menjanjikan di era revolusi industri 4.0. Promosi tidak perlu menyediakan biaya operasional yang besar. Cara pembayarannya lebih mudah, tidak harus pergi ke ATM untuk melakukan transfer uang. Namun sistem pembayaran Cash on Delivery, virtual account hingga berbagai pembayaran lewat perusahaan fintech telah membuat bisnis jualbeli online terus berkembang.

Berikut beberapa keuntungan apabila kita melakukan bisnis online, diantaranya:

- Bisa di jalankan di mana saja dan kapan saja, Hal pertama yang didapatkan saat menjalankan bisnis online ialah kemudahan dalam menjalankannya, tidak butuh tempat yang strategis, tidak butuh waktu khusus, tidak ada batasan hari, semuanya terserah pada diri kita. Asalkan ada sambungan internet di mana pun dan kapan pun bisa menjalankan bisnis online.

- Modal awal sesuai isi dompet Keuntungan kedua dari bisnis online ialah modal yang bisa di sesuaikan dengan kondisi finansial kita saat ini. Tak harus memiliki modal besar untuk menjalankan bisnis online, bahkan bisa memulai usaha ini tanpa modal sekalipun asalkan telah memiliki komputer, laptop, atau smartphone yang tersambung dengan jaringan internet.

- Bisnis dengan potensi internasional, Internet merupakan sebuah jaringan global yang bisa saling terhubung di seluruh dunia. Bisnis online yang sekarang dijalankan meskipun produk atau artikel yang dihasilkan dalam bahasa Indonesia akan tetap di cari oleh banyak orang di luar negeri. Jadi, dengan melakukan bisnis online, usaha yang dijalankan memiliki potensi internasional.

- Bisa sukses, apapun latar belakangnya Bisnis online bisa di jalankan oleh siapa

saja tak peduli apa latar belakangnya, agar bisa sukses dalam berbisnis online tentu saja diperlukan belajar mengenai bisnis online ini, bisa belajar melalui forum, website atau rekan-rekan pebisnis online.

\section{KESIMPULAN DAN SARAN \\ Kesimpulan}

Salah satu cara dalam menghadapi Revolusi Industri 4.0 ini adalah adanya 


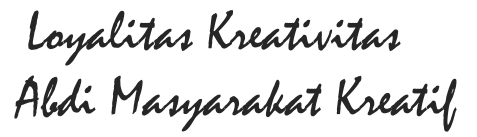

P-ISSN 2722-2101, E-ISSN 2722-4201

Program Studi Ekonomi Manajemen Universitas Pamulang Jurnal LOKABMAS Kreatif Vol.01,No.02 Juli 2020, Hal. 88-95

Email:jurnalkreatif.manajemen@gmail.com kesadaran setiap individu, khususnya para pelajar untuk berusaha menguasai keahlian atau skill untuk melahirkan tenaga kerja profesional, sehingga dapat beradaptasi dengan keberadaan kondisi saat ini.

Untuk bisa beradaptasi dengan revolusi industri 4.0, seseorang harus memiliki kemampuan yang tidak dapat dilakukan oleh mesin. Salah satu contohnya adalah kemampuan untuk memecahkan masalah atau kreativitas, di mana soft kompetensi merupakan kunci utamanya. Agar dapat menghadapi perubahan pada tahun-tahun mendatang, dibutuhkan masyarakat yang memiliki soft kompetensi seperti pemecahan masalah yang kompleks, pikiran yang kritis, kreativitas, manajemen manusia, berkoordinasi dengan orang lain, kecerdasan emosional, penilaian dan pengambilan keputusan, berorientasi servis, negosiasi, dan fleksibilitas kognitif.

Bagi yang sudah memiliki keahlian tetap harus berusaha meningkatkan keahliannya dan yang sudah memiliki keahlian tetapi tidak relevan maka harus segera merubahnya sesuai dengan kebutuhan pasar sekarang.

\section{Saran}

Berdasarkan pengalaman dari pelaksanaan kegiatan ini maka dapat diajukan saran sebagai berikut:

- Diharapkan kegiatan ini dapat dilaksanakan di berbagai sekolah untuk menginformasikan bagaimana pentingnya memiliki kompetensi yang berkualitas agar mampu menyesuaikan diri dan bersaing di era industry 4.0.

- Diharapkan kegiatan ini tidak dilakukan hanya sekali ini saja, namun bisa secara berkala sesuai kebutuhan, agar para pemimbing dapat melakukan pemantauan perkembangan para peserta dalam mengimplementasi materi yang disampaikan.

\section{DAFTAR PUSTAKA}

Badan Pusat Statistik. (2018). Agustus 2018: Tingkat Pengangguran Terbuka (TPT) sebesar 5,34 persen.

https://www.bps.go.id/pressrelease/2018/1 1/05/1485/agustus-2018-- tingkatpengangguran-terbuka--tpt--sebesar-5-34persen.html, 5 November 2018. Diakses tanggal 19 Desember 2018.

Hanrahmawan, F. (2012). Revitalisasi Manajemen Pelatihan Tenaga Kerja (Studi Kasus Pada Balai Latihan Kerja Industri Makassar). Jurnal Ilmiah Ilmu Administrasi Publik, $1(1)$
Kumawula,Vol.1,No.2, Agustus 2018, Hal 114119

DOI:http://10.24198/kumawula.v1i2.20 029 ISSN 2620-844X

Mangkunegara, Anwar Prabu, Evaluasi Kinerja Sumber Daya Manusia,edisi pertama, cetakan pertama, Refika Aditama, Bandung, 2005, hlm. 113

Evaluasi

Kinerja SDM, PT. Refika Aditama, Bandung, 2012.

Prasetyo, Hoedi dan Sutopo, Wahyudi.2018.Industri 4.0: Telaah klasifikasi aspek dan arah perkembangan riset. Jurnal Teknik Insdustri (J@TI). Volume 13.No.1. Halaman 17-18.

Pasaribu, V. L. D., Agrasadya, A., Shabrina, N., \& Krisnaldy, K. (2020). MENJADI

ENTERPRENEUR MUDA YANG MEMILIKI JIWA LEADERSHIP UNTUK MENGHADAPI MASA DEPAN. Abdi Laksana, 1(1)

Pasaribu, V. L. D., Elburdah, R. P., Sudarso, E., \& Fauziah, G. (2020). PENGGUNAAN MANAJEMEN WAKTU TERHADAP PENINGKATAN PRESTASI BELAJAR DI SMP ARAISIYAH. Jurnal ABDIMAS, 1(1)

Pasaribu, V. L. D., Susanti, F., \& Hartuti, E. T. K. (2019). MEMOTIVASI SISWA DAN SISWI SMK LETRIS INDONESIA DI DALAM MENENTUKAN PILIHAN UNTUK MELANJUTKAN PENDIDIKAN ATAU BEKERJA SETELAH LULUS SEKOLAH. Jurnal Pengabdian Dharma Laksana, 1(2), 161-172.

Pasaribu, V. L. D., Oktrima, B., Prabowo, B., Arianto, N., \& Haryoko, U. B. (2020). PROGAM PENDAMPINGAN DAN PENYELENGGARAAN PENDIDIKAN ANAK PADA USIA DINI TERHADAP PRESTASI BELAJAR DILINGKUNGAN RT 020 RW 009. KEL GIRI PENI. KEC WATES. YOGYAKARTA. JURNAL LOKABMAS KREATIF, 1(1), 71-75.

Pasaribu, V. L. D., Sulaiman, S., Sutiman, S., Thaharudin, T., \& Purnomo, B. Y. (2020). PENGENALAN LETAK POSYANDU TERDEKAT DIKELURAHAN PISANGAN 
Loyalitas Kreativitas
Aldi Masyarakat Kreatif

P-ISSN 2722-2101, E-ISSN 2722-4201

Program Studi Ekonomi Manajemen Universitas Pamulang Jurnal LOKABMAS Kreatif Vol.01,No.02 Juli 2020, Hal. 88-95 Email:jurnalkreatif.manajemen@gmail.com
DENGAN MANAJEMEN PEMASARAN REVOLUSI 4.0 UNTUK MENINGKATKAN PENGETAHUAN MASYARAKAT LETAK DAN FUNGSI POSYANDU TERDEKAT PADA KELURAHAN

PISANGAN. DEDIKASI PKM, 1(1), 105-110.

Pasaribu, V. L. D., \& Krisnaldy, K. (2019).

Manajemen Risiko dan Asuransi.

Wibowo, Manajemen Kinerja, Edisi Ketiga, PT RajaGrafindo Persada, Jakarta, 2013.

\section{DOKUMENTASI KEGIATAN}
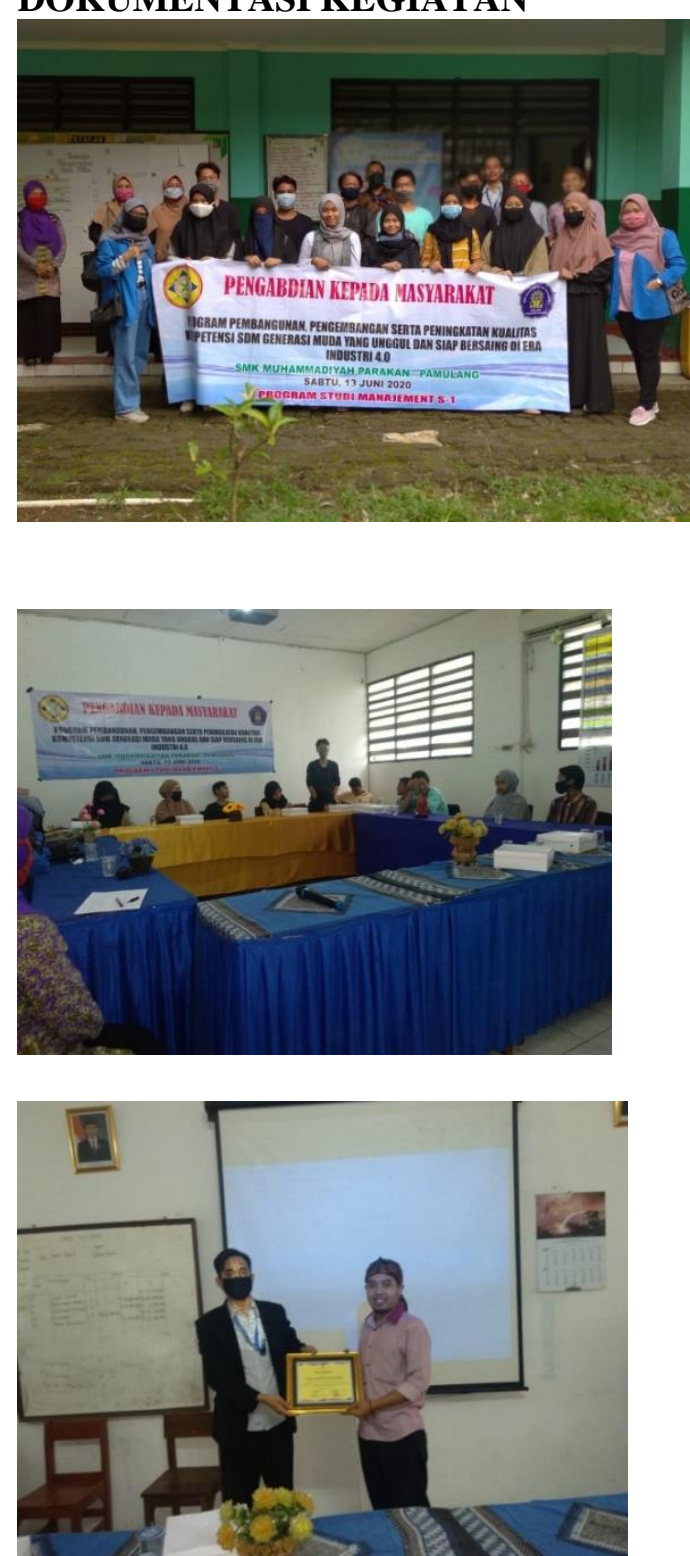
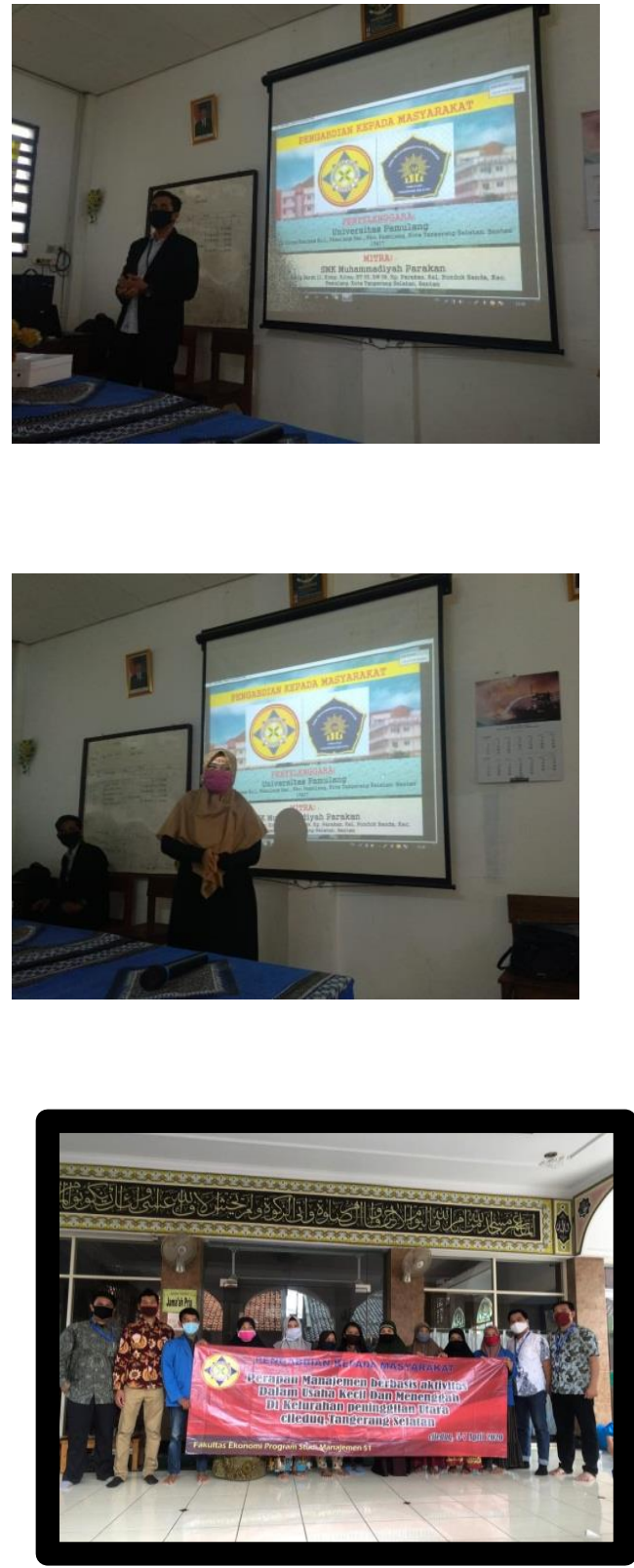
Loyalitas Kreativitas Aldi Masyarakat Kreatif
P-ISSN 2722-2101, E-ISSN 2722-4201

Program Studi Ekonomi Manajemen Universitas Pamulang

Jurnal LOKABMAS Kreatif Vol.01,No.02 Juli 2020, Hal. 88-95

Email:jurnalkreatif.manajemen@gmail.com 